【短 報】

\title{
RELATIONSHIP BETWEEN EXERCISE HYPERPNEA AND EXERCISE TOLERANCE IN PATIENTS ON CHRONIC HEMODIALYSIS
}

\author{
Kazuo TsuY'ki ${ }^{1)}$, Hiroyoshi YanO ${ }^{1)}$, Atsuo Kasugai ${ }^{1)}$, \\ Yasco Kimlra ${ }^{1)}$, Shinichi Watanabe ${ }^{2)}$, Hiroki $\mathrm{HaSE}^{3)}$, \\ Kenio Ebine ${ }^{3)}$ and KWANGCHOL $\mathrm{CHANG}^{4)}$
}

key words : hemodialysis, exercise hyperpea, maximal oxygen uptake

\section{Introduction}

It is known that exercise hyperpnea (EH) occurs during physical exertion in patients on chronic hemodialysis (HD). It is believed that $\mathrm{EH}$ prevents maximal physical activity and is a critical factor in limiting the quality of life. However. until now no objective evaluation of EH in patients on HD has been published. In the present study, we used the slope of minute ventilation to carbon dioxide production during incremental exercise $\left(\dot{\mathrm{VE}} / \mathrm{VCO}_{2} \text { slope }\right)^{1-4)}$ to evaluate $\mathrm{EH}$ in these patients. In addition, we investigated the relationship between $\mathrm{EH}$ and exercise tolerance in patients on HD.

\section{Subjects and Methods}

Two groups of subjects were included in the study. The first group, consisting of 63 patients with a mean age of $38.1 \pm 11.8$ years, had undergone regular hemodialysis for a mean duration of $29.3 \pm 29.5$ months. The underlying disease pro- cesses were chronic glomerulonephritis $(n=61)$, vesicoureteral reflux $(n=1)$, and chronic pyelonephritis $(n=1)$. Exclusion criteria included heart disease, diabetes mellitus, and liver dysfunc. tion. No patient was receiving therapy with beta blockers, antiarrhythmics, or digitalis. The second group, consisted of 59 healthy age-mached con. trols (mean age, $37.5 \pm 11.3$ years).

Patients were placed on a treadmill according to the modified Bruce protocol (Sheffield) on a non-dialysis day. The 12-lead electrocardiograph and heart rate were monitored throughout the test. Cuff blood pressure was measured every minute with a manual sphygmomanometer. Subjects were encouraged to continue the exercise until they perceived exhaustion in themselves. $\dot{\mathrm{V}} \mathrm{E}$ and $\dot{\mathrm{V}} \mathrm{CO}_{2}$ were measured continuously using a system -5 respiratory gas analyzer (AIC. Tokyo, Japan). The slope of $\dot{\mathrm{V}}$ and $\dot{\mathrm{V} C \mathrm{C}_{2}}$ was calculated by linear regression analysis with $\dot{\mathrm{V}} \mathrm{E}$ and $\dot{\mathrm{V}} \mathrm{CO}_{2}$ values obtained during exercise before the point of respiratory compensation. The maximum oxygen up-
1) 小田原循環器病院 干250-0873 神奈川県小田原市矢作296-1

2) 神奈川工科大学 厂243-0929 神奈川県厚木市下荻野1030

3) 東邦大学医学部付属大橋病院 于153-0045 東京都目黑区大橋2-17-16

4) 白鴎病院 干 250-0045 神奈川県足柄上郡開成町牛島270
Odawara Cardiovascular Hospital, 296-1 Yahagi, Odawara, Kanagawa 250-0873

Department of Welfare System Engineering. Kanagawa Iinstitute of Technorogy, 1030 Shimo-ogino. Atsugi, Kanagawa 243-0292 Department of Cardiovascular Surgery, Toho University School of Medicine, 2-17-6 Ohashi, Meguro, Tokyo 153-0044 Hakuoh Hospital, 270 Kaiseimachi, Ashigarakami, Kanagawa 258-0022 
take $\left(\dot{\mathrm{V}}_{2}\right.$ max $)$ was corrected with functional aerobic impairment (FAI) to exclude the effect of age and gender ${ }^{5)}$. FAI was calculated as follows :

$\mathrm{FAI}=\left(\right.$ predicted $\dot{\mathrm{VO}}_{2} \max$-observed $\dot{\mathrm{V}} \mathrm{O}_{2} \max$ )/predicted $\dot{\mathrm{V}} \mathrm{O}_{2} \max \times 100$

The results are expressed as the mean value \pm SD. The signifcant differences in ventilatory parameters were determined by the unpaired t-test. The relationship between $\mathrm{FAI}$ and the slope of the $\dot{\mathrm{VE}} / \dot{\mathrm{V}} \mathrm{CO}_{2}$ was assessed by linear regression analysis. $\mathrm{p}<0.05$ was considered significant.

\section{Results and Discussion}

No significant difference was seen between the healthy controls and patients on HD in ventilatory parameters at rest (Table 1). This suggests that the hyperventilation does not occur at rest, assuming HD is performed correctly and effectively. However, the slope of $\dot{\mathrm{V} E} / \dot{\mathrm{V}} \mathrm{CO}_{2}$ in patients on $\mathrm{HD}$ (36.9 \pm 4.7$)$ was significantly steeper than that of healthy controls $(27.9 \pm 3.6)$. The values obtained in this study for healthy controls were similar to those reported by Metra ${ }^{1)}$ and Reindl ${ }^{2)}$ in healthy individuals (28.0 44 and $27.4 \pm 3.5$, respectively), while values for patients on HD were similar to those reported by Clark et al. ${ }^{3)}$ and Levra et al. ${ }^{4)}$ for patients with severe chronic heart failure (the measured values were $37.8 \pm 9.0$ and $36.7 \pm 13.1$

Table 1. Comparison of ventilatory parameters between patients with HD and healthy controls at rest and during exercise.

\begin{tabular}{|c|c|c|}
\hline Variables & Controls & HD patients \\
\hline \multicolumn{3}{|l|}{ Rest } \\
\hline$\dot{\mathrm{VE}}(\mathrm{ml} / \mathrm{kg} / \mathrm{min})$ & $140.9 \pm 28.7$ & $134.9 \pm 21.6$ \\
\hline$\dot{\mathrm{V}} \mathrm{O}_{2}(\mathrm{ml} / \mathrm{kg} / \mathrm{min})$ & $3.57 \pm 0.40$ & $3.55 \pm 0.44$ \\
\hline$\dot{\mathrm{V} C O}{ }_{2}(\mathrm{ml} / \mathrm{kg} / \mathrm{min})$ & $2.98 \pm 0.44$ & $2.82 \pm 0.46$ \\
\hline$\dot{\mathrm{VE}} / \dot{\mathrm{V}} \mathrm{CO}_{2}$ & $47.2 \pm 6.0$ & $48.1 \pm 4.7$ \\
\hline$\dot{\mathrm{VE}} / \mathrm{V}_{2}$ & $39.7 \pm 7.7$ & $38.2 \pm 5.8$ \\
\hline$\dot{\mathrm{V} C O}{ }_{2} / \dot{\mathrm{V}}_{2}$ & $0.84 \pm 0.09$ & $0.80 \pm 0.12$ \\
\hline $\mathrm{RR}($ time $/ \mathrm{min})$ & $14.1 \pm 4.0$ & $14.7 \pm 3.8$ \\
\hline $\mathrm{VT}(\mathrm{ml} / \mathrm{kg} / \mathrm{min})$ & $10.8 \pm 4.0$ & $9.6 \pm 2.5$ \\
\hline \multicolumn{3}{|l|}{ Submaximum } \\
\hline$\dot{\mathrm{V} E} / \dot{\mathrm{V}} \mathrm{CO}_{2}$ slope & $27.9 \pm 3.6$ & $36.9 \pm 4.7^{*}$ \\
\hline $\mathrm{AT}(\mathrm{ml} / \mathrm{kg} / \mathrm{min})$ & $24.5 \pm 5.0$ & $17.6 \pm 3.6^{*}$ \\
\hline OUES & $2307.9 \pm 645.4$ & $1490.5 \pm 366.8^{*}$ \\
\hline \multicolumn{3}{|l|}{ Maximum } \\
\hline$\dot{\mathrm{VE}}(\mathrm{ml} / \mathrm{kg} / \mathrm{min})$ & $1295.0 \pm 318.5$ & $1037.0 \pm 262.1^{*}$ \\
\hline$\dot{\mathrm{V}} \mathrm{O}_{2}(\mathrm{ml} / \mathrm{kg} / \mathrm{min})$ & $37.43 \pm 7.5$ & $25.5 \pm 5.0^{*}$ \\
\hline$\dot{\mathrm{V} C O}{ }_{2}(\mathrm{ml} / \mathrm{kg} / \mathrm{min})$ & $40.8 \pm 8.2$ & $25.7 \pm 6.4^{*}$ \\
\hline$\dot{\mathrm{VE}} / \dot{\mathrm{V}} \mathrm{CO}_{2}$ & $31.8 \pm 4.0$ & $40.6 \pm 4.9^{*}$ \\
\hline$\dot{\mathrm{VE}} / \dot{\mathrm{VO}}_{2}$ & $34.7 \pm 5.0$ & $42.0 \pm 6.2^{*}$ \\
\hline$\dot{\mathrm{V} C O}{ }_{2} / \dot{\mathrm{V}}_{2}$ & $1.10 \pm 0.09$ & $1.04 \pm 0.08$ \\
\hline $\mathrm{RR}($ time/min) & $41.3 \pm 7.1$ & $39.1 \pm 7.5$ \\
\hline $\mathrm{VT}(\mathrm{ml} / \mathrm{kg} / \mathrm{min})$ & $31.4 \pm 5.5$ & $27.0 \pm 6.1^{*}$ \\
\hline FAI $(\%)$ & $4.5 \pm 16.2$ & $30.7 \pm 13.0^{*}$ \\
\hline
\end{tabular}

$\dot{V} \mathrm{E}$ : minute vetilation; $\dot{\mathrm{V}} \mathrm{O}_{2}$ : oxygen uptake : $\dot{\mathrm{V}} \mathrm{CO}_{2}$ : carbon dioxide production ; RR : respiration rate ; VT : tidal volume ; FAI : functional aerobic impairment ; AT : anaero. bic ventilatory threshold; OUES : oxygen uptake efficiency slope.

* $: \mathrm{p}<0.001$ cf. controls 


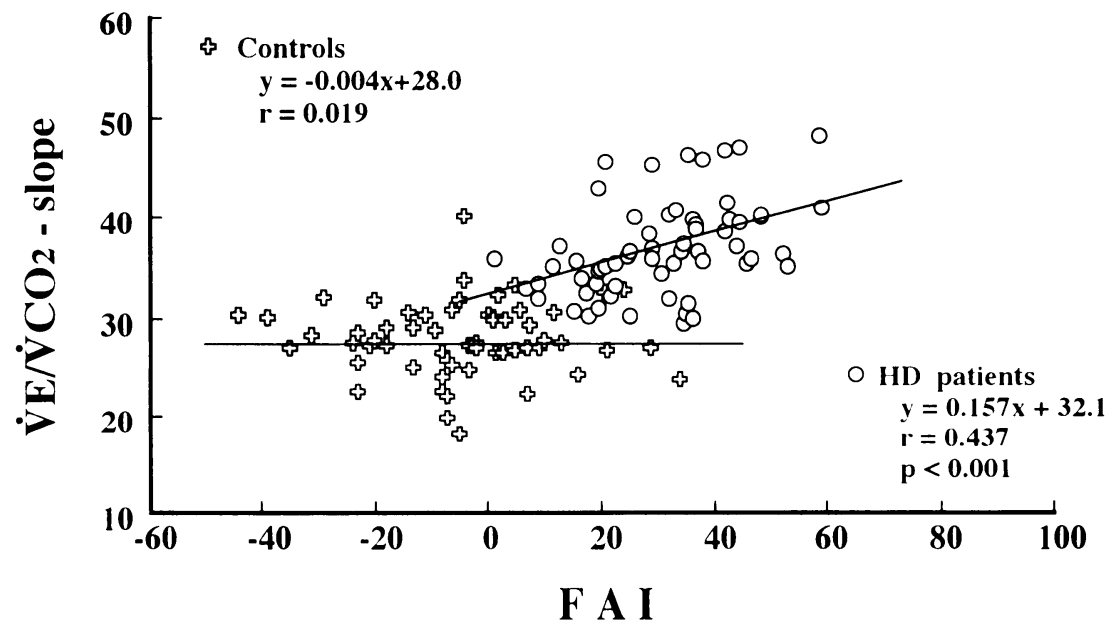

Fig. 1. Relationship between functional aerobic impairment (FAI) and the slope of ventilation to carbon dioxide production in patients on chronic hemodialysis (open circle) and healthy controls (open cross).

for patients with left ventricular ejection fraction of $25.9 \pm 3.4 \%$ and $25.8 \pm 14.8 \%$, respectively). These findings suggest that $\mathrm{EH}$ in patients on $\mathrm{HD}$ is substantially greater than in healthy indi. viduals, occurring on the same order as in pa. tients with severe chronic heart failure.

Adequate investigations have not yet been con. ducted on the mechanism of EH in HD patients : and the present study has not clarified the matter. However, it appears that an important contribution is made by pathologic factors such as an increase of the physiologic dead space ventilation ${ }^{6)}$ caused by a decrease in pulmonary perfusion ${ }^{7)}$ and a decrease in pulmonary diffusion capacity due to calcification ${ }^{8)}$, occurrence of metabolic acidosis early in exercise ${ }^{9)}$, and anemia associated with renal failure.

No correlation between the slope of $\dot{\mathrm{V}} / \mathrm{V} \mathrm{VO}_{2}$ and either age or gender was found in any group, indicating that this slope can be used to evaluate EH without concern over the affect of these fac. tors.

In patients on $\mathrm{HD}$, a positive correlation was seen between the $\dot{\mathrm{V}} / \dot{\mathrm{V}} \mathrm{CO}_{2}$ slope and FAI, while no such correlation was found in normal controls
(Fig. 1). Although the association between slope of $\dot{\mathrm{VE}} / \mathrm{V} \mathrm{CO}_{2}$ and exercise tolerance in healthy in. dividuals was not established in a previous report ${ }^{1)}$, this study supports the conclusion that exercise tolerance and $\mathrm{EH}$ are not related. On the con. trary, a positive correlation was seen between the slope of $\dot{\mathrm{V} E} / \dot{\mathrm{V} C O} \mathrm{O}_{2}$ and exercise tolerance in patients on HD, suggesting that the pathology associated with EH may be related to exercise tolerance.

In conclusion, these findings suggest that the slope of $\dot{\mathrm{V} E} / \dot{\mathrm{V} C \mathrm{CO}_{2}}$ is useful for correlating $\mathrm{EH}$ with exercise tolerance in patients on HD.

(Accepted Dec. 18, 2000)

\section{References}

1) Metra, M., Dei, C. L., Panina,G., Visioli, O., Exercise hyperventilation in chronic congestive heart failure, and its relation to functional capacity and hemody. namic, Am. J. Cardiol., (1992), 70, 622-628

2) Reindl, I. and Kleber, F. X. , Exertional hyperpnea in patients with chronic heart failure is a reversible cause of exercise intolerance, Basic Res. Cardiol., (1996), 91. Suppl 1 37-43

3) Clark, A. L., Volterrani, M., Swan, J. W., Coats A. J. S., The increased Ventilatory response to exercise in chroinc heart failure: relation to pulmonary pathology. Heart (1997). 77, 138-146 
4) Leyva, F., Anker S., Godsland. I. F., Wingrove, C. S., Chua, T. P., Stevenson, J. S. and Coats, A. J. S.. Serum urin acid as an index of impaired oxidative metabolism in chronic heart failure. Eur. heart J. (1997), 18, 858-865

5) Hase, H., Watanabe, S., Nakamura, R., Yabuki, S., Machii, K., Lee, M., Ebine, K., Akaike, M., Tsuyuki, K., Chang, K., Effects of exercise training on functional aerobic capacity, cadiac function and peripheral circulatory function in chronic hemodialysis patients. Jpn. J. Nephro. (1985), 27, 14291436 (in japanese)

6) Romaldini, H., Stabile, C., Faro, S., Santos, M. L. D., Ramos, O. L., Ratto, O. R., Pulmonary ventilation during hemodialysis. Nephron, (1982), 32, 131-134

7) Faubert, P. F., Shapiro, W. B., Porush. J. G., Chou, S. Y., Gross, J. M., Bondi, E., Leon, G. G., Pulmonary calcification in hemodialysis patients detected by technetium-99 m diphoshonate scannig. Kidney Int., (1980), 18, 95-102

8) Forman, J. W., Ayers, L. N., Miller, W. C., Pulmonary diffusion capacity in chronic renal failure. $\mathrm{Br}$. J. Dis. Chest, (1981) , 75, 81-87

9) Durozard, D., Pimmel, P., Baretto, S., Caillette, A., Labeeuw, M., Baverel, G., Zech, P., ${ }^{31}$ P NMR spectroscopy investigation of muscle metabolis $m$ in hemodialysis patients. Kidney Int., (1993), 43, 885892 